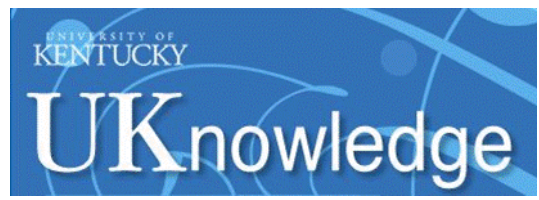

University of Kentucky

UKnowledge

Biosystems and Agricultural Engineering

Faculty Publications

Biosystems and Agricultural Engineering

2013

\title{
Influence of Flue Gas Components on the Growth Rate of Chlorella vulgaris and Scenedesmus acutus
}

\author{
Czarena Crofcheck \\ University of Kentucky, crofcheck@uky.edu \\ Aubrey Shea \\ University of Kentucky, aubrey.shea@uky.edu \\ Michael D. Montross \\ University of Kentucky, michael.montross@uky.edu \\ Mark Crocker \\ University of Kentucky, Mark.crocker@uky.edu \\ Rodney Andrews \\ University of Kentucky, rodney.andrews@uky.edu
}

Follow this and additional works at: https://uknowledge.uky.edu/bae_facpub

Part of the Algae Commons, Bioresource and Agricultural Engineering Commons, and the Oil, Gas, and Energy Commons

Right click to open a feedback form in a new tab to let us know how this document benefits you.

\section{Repository Citation}

Crofcheck, Czarena; Shea, Aubrey; Montross, Michael D.; Crocker, Mark; and Andrews, Rodney, "Influence of Flue Gas Components on the Growth Rate of Chlorella vulgaris and Scenedesmus acutus" (2013). Biosystems and Agricultural Engineering Faculty Publications. 29.

https://uknowledge.uky.edu/bae_facpub/29

This Article is brought to you for free and open access by the Biosystems and Agricultural Engineering at UKnowledge. It has been accepted for inclusion in Biosystems and Agricultural Engineering Faculty Publications by an authorized administrator of UKnowledge. For more information, please contact UKnowledge@lsv.uky.edu. 


\section{Influence of Flue Gas Components on the Growth Rate of Chlorella vulgaris and}

Scenedesmus acutus

\section{Digital Object Identifier (DOI)}

https://doi.org/10.13031/trans.56.10094

\section{Notes/Citation Information}

Published in Transactions of the ASABE, v. 56, issue 6, p. 1421-1429.

(C) 2013 American Society of Agricultural and Biological Engineers

The copyright holder has granted the permission for posting the article here. 


\title{
INFLUENCE OF FLUE GAS COMPONENTS ON THE GROWTH RATE OF CHLORELLA VULGARIS AND SCENEDESMUS ACUTUS
}

\author{
C. Crofcheck, A. Shea, M. Montross, M. Crocker, R. Andrews
}

\begin{abstract}
Atmospheric carbon dioxide levels have increased since the industrial revolution due to the increase in combustion of fossil fuels. One possible alternative strategy is the use of microalgae for $\mathrm{CO}_{2}$ capture and recycling. Major components in coal-derived flue gas that may accumulate and effect algae growth include both sulfur oxides and fly ash. However, in practical application, sulfur oxides will be converted quickly to the acid product $\left(\mathrm{H}_{2} \mathrm{SO}_{4}\right)$ in the aerobic aqueous conditions of algae cultivation. In this article, the influence of elevated $\mathrm{H}_{2} \mathrm{SO}_{4}$ levels and the presence of coal-derived fly ash were investigated. As the $\mathrm{H}_{2} \mathrm{SO}_{4}$ level increased, algae growth was inhibited and finally ceased; however, this affect could be minimized by the addition of $\mathrm{NaHCO}_{3}$ as a buffer. The effect of ash on the growth of algae was related to the type of coal-fired combustion and the amount of ash. For one of the ash types tested, the algae growth rate actually increased at a low ash concentration. In this work, major technical hurdles in the use of algal scrubbing systems are being addressed with respect to major contaminants in coal-derived flue gases.
\end{abstract}

Keywords. Algae, Chlorella, $\mathrm{CO}_{2}$ mitigation, Flue gas, Scenedesmus.

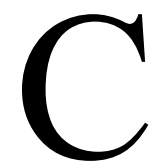

oal-fired power plants alone emit about 1.9 billion metric tons of $\mathrm{CO}_{2}$ annually, representing $33 \%$ of energy-related $\mathrm{CO}_{2}$ emission from the U.S. in 2008 (EIA, 2009). Currently, the most promising technologies under development to capture $\mathrm{CO}_{2}$ from coal-fired power plants include post-combustion, precombustion, or oxy-combustion, with $\mathrm{CO}_{2}$ transportation to a storage site via pipeline. In addition to this high energy consumption, chemical absorption and geological storage of $\mathrm{CO}_{2}$ have high capital cost and the potential problem of gas leakage. Consequently, these drawbacks are encouraging researchers to find alternative approaches for the mitigation of $\mathrm{CO}_{2}$ emissions. One possible strategy is the use of microalgae for $\mathrm{CO}_{2}$ capture and recycling (Sayre, 2010; Wang et al., 2008; Ho et al., 2011).

Although microalgae exist and thrive almost everywhere on Earth, not all strains are suitable for the capture of $\mathrm{CO}_{2}$ from flue gas. Flue gas is emitted from coal power plants at a relatively high temperature, even after heat recovery, and usually contains $10 \%$ to $15 \% \mathrm{CO}_{2}$. If closed photobioreactors are chosen for the bio-mitigation system, the operating temperature often exceeds ambient. Therefore, two primary properties of the ideal strain should be tolerance of high

Submitted for review in January 2013 as manuscript number FPE 10094; approved for publication by the Food \& Process Engineering Institute of ASABE in October 2013.

This article is published with the approval of the Director of the Kentucky Agricultural Experiment Station as Paper No. 13-05-136.

The authors are Czarena Crofcheck, ASABE Member, Associate Professor, Aubrey Shea, Engineering Associate, and Michael Montross, ASABE Member, Professor, Department of Biosystems and Agricultural Engineering; Mark Crocker, Associate Director, and Rodney Andrews, Director, Center for Applied Energy Research, University of Kentucky, Lexington, Kentucky. Corresponding author: Czarena Crofcheck, 128 CE Barnhart Building, University of Kentucky, Lexington, KY 40546 ; phone: 859-257-3000, ext. 212; e-mail: crofcheck@uky.edu.
$\mathrm{CO}_{2}$ concentrations and high temperatures. With these goals in mind, the search for ideal strains has been ongoing for decades. Researchers have isolated and selected various strains from high temperature $\left(30^{\circ} \mathrm{C}\right.$ to $\left.70^{\circ} \mathrm{C}\right)$ and high $\mathrm{CO}_{2}$ locations, such as warm natural carbonate springs (Sakai et al., 1995; Westerhoff et al., 2010), wastewater treatment facilities (de-Bashan et al., 2008), and artificial extreme conditions (Morais and Costa, 2007).

From a historical perspective, Chlorophyta is one of most studied groups of microalgae in terms of $\mathrm{CO}_{2}$ biomitigation and biofuel production. Among the particularly promising genera, Chlorella and Scenedesmus have been the most studied to date. Chlorella occurs as 2 to $12 \mu \mathrm{m}$ spherical or ellipsoidal unicells thriving in fresh and marine waters and soils (Graham and Wilcox, 2000). Molecular phylogenetic analyses indicate that Chlorella is polyphyletic and descended from multiple ancestors. Scenedesmus typically appears as a flat colony of 4,8 , or 16 linearly arranged cells growing in fresh and occasionally brackish water (Graham and Wilcox, 2000).

One crucial issue to be addressed is the toxicity of flue gas components on the growth of microalgae. Flue gas generated from coal combustion typically consists of $\sim 75.8 \%$ $\mathrm{N}_{2}, 13.2 \% \mathrm{CO}_{2}, 6.2 \% \mathrm{H}_{2} \mathrm{O}$, and $4.8 \% \mathrm{O}_{2}$ (mole-fraction) (Desideri and Paolucci, 1999). In addition to these major components, flue gas also contains trace amounts of $\mathrm{NO}_{\mathrm{x}}$ and $\mathrm{SO}_{\mathrm{x}}$ (100 to $300 \mathrm{ppm}$ ) (Lee et al., 2002). Once dissolved in water, $\mathrm{NO}_{\mathrm{x}}$ and $\mathrm{SO}_{\mathrm{x}}$ become acids and account for the formation of acid rain when released into the atmosphere. When culture $\mathrm{pH}$ is not controlled within the tolerance range of algal growth $(\sim 7.0)$, high concentrations of $\mathrm{SO}_{\mathrm{x}}$ and $\mathrm{NO}_{\mathrm{x}}$ can show significant inhibition on the growth of some algae species. In a study of the effects of simulated flue gas with $200 \mathrm{ppm} \mathrm{SO}_{2}$, the growth of Chlorella vulgaris was significantly inhibited, while Chlorella 
caldarium was not dramatically affected due to its acidophilic characteristics (Hauck at al., 1996). When a series of $\mathrm{SO}_{2}$ concentrations $(0,60,100$, and $150 \mathrm{ppm})$ were introduced to the cultivation media of Chlorella sp. KR-1, the growth rates $\left(\mathrm{g} \mathrm{L}^{-1} \mathrm{~d}^{-1}\right)$ were accordingly decreased from 1.66 to close to zero with increasing $\mathrm{SO}_{2}$ concentration (Lee et al., 2002). The growth rate decline is probably associated with a fall in the $\mathrm{pH}$ from 7 to 3 . Therefore, appropriately buffering the medium can be a solution to maintain normal growth of algae with the addition of flue gas. Maeda et al. (1995) suggested the use of $\mathrm{CaCO}_{3}$ to prevent the decrease in $\mathrm{pH}$ and subsequent death of algae (Chlorella sp. T-1). Without addition of $\mathrm{CaCO}_{3}$, a gas mixture of $\mathrm{SO}_{\mathrm{x}}(80 \mathrm{ppm})$ and $\mathrm{NO}_{\mathrm{x}}(240 \mathrm{ppm})$ quickly acidified the culture medium, and growth ceased. After adding $\mathrm{CaCO}_{3}$, the growth rate showed a marginal decrease. Similarly, it is reported that if the flue gas flow rate is constantly adjusted according to the medium $\mathrm{pH}$ (chemostat), algae exhibit a certain degree of tolerance of $\mathrm{SO}_{x}$ and $\mathrm{NO}_{x}$ (Zeiler et al., 1995; Olaizola, 2003). In addition to acidic components, the ash present in flue gases is also reported to alter the growth of algae, such that the algae productivity starts decreasing when the ash (containing $\mathrm{V}_{2} \mathrm{O}_{5}, \mathrm{NiO}, \mathrm{Fe}_{2} \mathrm{O}_{3}$, $\mathrm{Al}_{2} \mathrm{O}_{3}$, and $\mathrm{CaO}$ ) concentration is higher than $0.2 \mathrm{~g} \mathrm{~L}^{-1}$ (Matsumoto et al., 1997).

This article focuses on the influence of two of the major flue gas components, $\mathrm{SO}_{\mathrm{x}}$ and ash, on the growth rate of two microalgae strains, Chlorella vulgaris and Scenedesmus acutus, both well suited for $\mathrm{CO}_{2}$ capture.

\section{Materials ANd Methods \\ Culture Preparation}

Chlorella vulgaris (\#152075) was obtained from the algae collection at Carolina Biological Supply Company (Burlington, N.C.). Scenedesmus acutus (UTEX 72) was purchased from the algae culture collection at the University of Texas at Austin. Seed cultures of Chlorella vulgaris and Scenedesmus were grown and maintained in urea media containing urea $\left(0.55 \mathrm{~g} \mathrm{~L}^{-1}\right), \mathrm{KH}_{2} \mathrm{PO}_{4}\left(0.1185 \mathrm{~g} \mathrm{~L}^{-1}\right)$, $\mathrm{CaCl}_{2} \cdot 2 \mathrm{H}_{2} \mathrm{O}\left(0.055 \mathrm{~g} \mathrm{~L}^{-1}\right), \mathrm{MgSO}_{4} \cdot 7 \mathrm{H}_{2} \mathrm{O}\left(0.109 \mathrm{~g} \mathrm{~L}^{-1}\right)$, and $\mathrm{Na} \cdot$ EDTA $\cdot \mathrm{Fe}\left(0.02 \mathrm{~g} \mathrm{~L}^{-1}\right)$ (Crofcheck et al., 2012). Media were prepared with municipal drinking water (dechlorinated with $0.06 \mathrm{~g}$ sodium thiosulfate per $2 \mathrm{~L}$ of medium) and filtered through a $0.2 \mu \mathrm{m}$ Nalgene nylon membrane filter (47 mm diameter). Once a week, microalgal cells were transferred into new media for subculture or used as inoculums for an experiment. Working in a laminar flow hood, $2 \mathrm{~mL}$ liquid stock culture was transferred to $400 \mathrm{~mL}$ fresh medium in a $500 \mathrm{~mL}$ Erlenmeyer flask. Newly transferred flasks were incubated under warm (F32T8/TL741 Alto, $32 \mathrm{~W}$, Philips) and cool (F32T8/TL735 Alto, $32 \mathrm{~W}$, Philips) white fluorescent lights $\left(70 \mu \mathrm{mol} \mathrm{m} \mathrm{m}^{-2} \mathrm{~s}^{-1}\right)$ in a $16: 8 \mathrm{~h}$ light:dark illumination period. Flasks were bubbled with $3 \%$ anaerobic-grade cylinder $\mathrm{CO}_{2}\left(0.14 \mathrm{~L} \mathrm{~min}^{-1} \mathrm{CO}_{2}\right.$ and $4.4 \mathrm{~L} \mathrm{~min}^{-1}$ air for the total system of flasks), the percentage of $\mathrm{CO}_{2}$ being selected to achieve saturation of the flask with $\mathrm{CO}_{2}$. All experimental flasks were placed on a shaking table $(100 \mathrm{rpm})$ and kept at room temperature $\left(22^{\circ} \mathrm{C}\right)$.

\section{DRY WEIGHT AND GROWTH RATE}

Chlorella and Scenedesmus biomass samples in suspension were filtered using Whatman binder-free glass microfiber filters (type 934-AH, $24 \mathrm{~mm}$ diameter). Ash free dry weight (AFDW) values were obtained by first drying algae samples at $105^{\circ} \mathrm{C}$ for $24 \mathrm{~h}$ and then ashing them at $550^{\circ} \mathrm{C}$ for $1 \mathrm{~h}$ (Becker, 1994). Since ash was added to some of the flasks, and the media may have contained some salts or minerals, an ash free dry weight basis was employed to ensure accurate measurement of biological growth. Growth curves of cultivation time versus AFDW were linear for the growth periods studied; hence, the slope of the growth curve was used as the growth rate $\left(\mathrm{mg} \mathrm{L}^{-1} \mathrm{~h}^{-1}\right)$.

\section{Experimental Procedure}

Chlorella and Scenedesmus were grown in triplicate in an environmental chamber $\left(22^{\circ} \mathrm{C}\right)$. For both cultures, a target inoculum value of $0.1 \mathrm{~g} \mathrm{~L}^{-1}$ (dry weight) was cultured in $400 \mathrm{~mL}$ of medium with $3 \%$ enriched $\mathrm{CO}_{2}$ /air mixture. Gas flow rates of $0.14 \mathrm{~L} \mathrm{~min}^{-1} \mathrm{CO}_{2}$ and $4.40 \mathrm{~L} \mathrm{~min}^{-1}$ air were regulated with a mass-flow controller (model $5850 \mathrm{E}$, Brooks Instrument, Hatfield, Pa.) and a flow meter (model VA20439, Dwyer Instrument, Inc., Michigan City, Ind.), respectively. The culture was illuminated with warm and cool white fluorescent light in a $16 \mathrm{~h}: 8 \mathrm{~h}$ light:dark cycle $\left(70 \mu \mathrm{mol} \mathrm{m} \mathrm{m}^{-2}\right)$. Algae dry weight and $\mathrm{pH}$ were measured every $24 \mathrm{~h}$.

\section{SO $_{\mathrm{x}}$ ACIDIFICATION EXPERIMENTS}

Chlorella and Scenedesmus were both tested for their tolerance of $\mathrm{SO}_{\mathrm{x}}$. When $\mathrm{SO}_{2}$ comes into contact with water, it forms sulfurous acid $\left(\mathrm{H}_{2} \mathrm{SO}_{3}\right)$, which is rapidly oxidized to sulfuric acid $\left(\mathrm{H}_{2} \mathrm{SO}_{4}\right)$ (Loerting et al., 2000). Therefore, to mimic the effect of $\mathrm{SO}_{2}$, sulfuric acid was used. A sulfuric acid solution ( $1 \mathrm{M} \mathrm{H}_{2} \mathrm{SO}_{4}$ ) was added to urea media in varying amounts (0 to $120 \mathrm{ppm}$ ) while bubbling $3 \% \mathrm{CO}_{2}$. Next, Chlorella was incubated in the $\mathrm{H}_{2} \mathrm{SO}_{4}$-doped media with $3 \% \mathrm{CO}_{2}$ for $8 \mathrm{~h}$. Using smaller increments of 0 to 120 ppm $\mathrm{H}_{2} \mathrm{SO}_{4}$, Scenedesmus was cultured in both the $\mathrm{H}_{2} \mathrm{SO}_{4}$-doped urea media and the same media prepared with addition of a buffer (urea medium with $1 \mathrm{~g} \mathrm{~L}^{-1} \mathrm{Na}$ $\mathrm{HCO}_{3}$ ), using 3\% $\mathrm{CO}_{2}$. For $\mathrm{H}_{2} \mathrm{SO}_{4}$ levels above $120 \mathrm{ppm}$, the algae did not survive the $8 \mathrm{~h}$ culture time. The $\mathrm{CO}_{2}$ level was maintained at saturation levels with the continuous introduction of $\mathrm{CO}_{2}$, such that increasing the concentration further would not result in an increase in the $\mathrm{CO}_{2}$ concentration in the flask.

\section{ASH EXPERIMENTS}

Ash from four different coal-fired plants in Kentucky was available for testing. Ash samples were taken from the ash silos at the plant as grab samples, following standard power industry sampling techniques for ash analysis. The samples were representative of what would be expected from the units they were collected from based on previous samples from these units taken over the last decade (Hower et al., 2009).

The ash samples were labeled based on the ash type and amount of residual carbon present. Details concerning the various ash samples are given in tables 1 and 2. Loss on 
Table 1. Summary of ash samples used with Scenedesmus (SC) and Chlorella vulgaris (CV) tolerance tests.

\begin{tabular}{|c|c|c|c|c|c|c|}
\hline Label & $\begin{array}{c}\text { Feedstock } \\
{\text { (Bituminous Coal })^{[\mathrm{a}]}}\end{array}$ & Combustor $^{[\mathrm{b}]}$ & $\begin{array}{c}\text { Residual Carbon }^{[\mathrm{c}]} \\
(\%)\end{array}$ & Ash Type ${ }^{[\mathrm{d}]}$ & $\begin{array}{c}\mathrm{LOI}^{[\mathrm{e}]} \\
(\%) \\
\end{array}$ & $\begin{array}{l}\text { Strain } \\
\text { Tested }\end{array}$ \\
\hline Ash C-1\% & High sulfur & $\mathrm{CFBC}$ & 0.7 & Class C & 15 & $\mathrm{SC}, \mathrm{CV}$ \\
\hline Ash F-19\% & Compliance & PC & 19.2 & Class F & 15 & $\mathrm{SC}, \mathrm{CV}$ \\
\hline Ash F-3\% & Compliance & $\mathrm{PC}$ & 3.0 & Class F & 4 & $\mathrm{CV}$ \\
\hline Ash F-11\% & Compliance & $\mathrm{PC}$ & 11.2 & Class F & $5-7$ & $\mathrm{SC}$ \\
\hline
\end{tabular}

[a] High sulfur $=>3$ lbs S per million BTU; compliance $=\sim 1.2$ lbs S per million BTU.

[b] $\quad \mathrm{CFBC}=$ circulating fluidized bed combustor; $\mathrm{PC}=$ pulverized coal combustor (standard technology).

[c] Residual carbon $=$ residual unburned carbon particulate in ash.

[d] Ash type = classifications of Class C or F based on ASTM defined standards for fly ash.

[e] LOI = loss on ignition, i.e., mass loss due to complete combustion of sample in excess oxygen.

Table 2. Elemental composition of ash samples used in this study.

\begin{tabular}{ccccc}
\hline & Ash C-1\% & Ash F-19\% & Ash F-3\% & Ash F-11\% \\
\cline { 2 - 5 } & \multicolumn{5}{c}{$(\%)$} \\
$\mathrm{C}$ & 0.7 & 19.2 & 3 & 11.2 \\
$\mathrm{SiO}_{2}$ & 15.1 & 52 & 53.9 & 54 \\
$\mathrm{Al}_{2} \mathrm{O}_{3}$ & 6 & 31.7 & 29.3 & 31.2 \\
$\mathrm{Fe}_{2} \mathrm{O}_{3}$ & 2.8 & 7.1 & 5.4 & 5.9 \\
$\mathrm{CaO}$ & 52.1 & 2 & 2.4 & 1.6 \\
$\mathrm{MgO}$ & 2 & 1 & 1.1 & 1 \\
$\mathrm{Na}_{2} \mathrm{O}$ & 0.3 & 0.2 & 0.4 & 0.3 \\
$\mathrm{~K}_{2} \mathrm{O}$ & 0.5 & 2.3 & 3.2 & 2.6 \\
$\mathrm{P}_{2} \mathrm{O}_{5}$ & 0.1 & 0.4 & 0.2 & 0.4 \\
$\mathrm{SO}$ & 22.4 & 0.3 & 0.6 & 0.2 \\
\hline & \multicolumn{5}{c}{$(\mathrm{ppm})$} & \\
$\mathrm{V}$ & 0 & 408.5 & 468.2 & 450.7 \\
$\mathrm{Mn}$ & 19 & 166.5 & 310.5 & 156 \\
$\mathrm{Co}$ & 0 & 27 & 31.3 & 29.2 \\
$\mathrm{Ni}$ & 0 & 114 & 166 & 156.5 \\
$\mathrm{Cu}$ & 0 & 254.5 & 414.2 & 324.5 \\
$\mathrm{Zn}$ & 0 & 136.5 & 350.6 & 239.7 \\
$\mathrm{Mo}$ & 0 & 215 & 98.3 & 201.2 \\
\hline
\end{tabular}

ignition (LOI) was measured using a Leco TGA701 (Leco Corp., St. Joseph, Mich.) following ASTM Standard D7348. Percent carbon was measured using a Leco CHN628 following ASTM Standard 3178. Major and minor elements were measured using a Panalytical PW2404 XRF (Panalytical B.V., Almelo, The Netherlands) following ASTM Standard D4326. The Ash C-1\% plant runs a circulating fluidized bed combustor (CFBC), which uses Illinois Basin coal as its feedstock and limestone in the combustor as a sorbent, producing a Class $\mathrm{C}$ ash (AS C618). This ash is much coarser than the other ash samples since it contains calcined limestone; indeed, as the data in table 2 show, it contains a high proportion of $\mathrm{Ca}$ and $\mathrm{S}$ (the latter present as sulfate), along with minimal carbon (due to the design of the CFBC). The other three ash samples were from plants running a pulverized coal combustor (PC, standard technology).

Ash toxicity studies were done with a high loading of ash, $5 \mathrm{~g} \mathrm{~L}^{-1}$, for both Scenedesmus and Chlorella. The ash tolerance studies were performed by adding no ash and $0.025,0.25$, and $0.5, \mathrm{~g} \mathrm{~L}^{-1}$ of Ash F-11\%, Ash C-1\%, and Ash F-19\% $(n=3)$. Cultures were incubated in an environmental chamber at $22^{\circ} \mathrm{C}$ with $3 \% \mathrm{CO}_{2}\left(0.394 \mathrm{~L} \mathrm{~min}^{-1}\right.$ $\mathrm{CO}_{2}$ and $12.75 \mathrm{~L} \mathrm{~min}^{-1}$ air for 30 flasks).

\section{RESULTS AND DiSCUSSION}

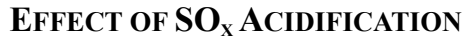

The addition of $\mathrm{CO}_{2}$ during the $\mathrm{H}_{2} \mathrm{SO}_{4}$ study would be expected to decrease $\mathrm{pH}$ due to hydration to carbonic acid

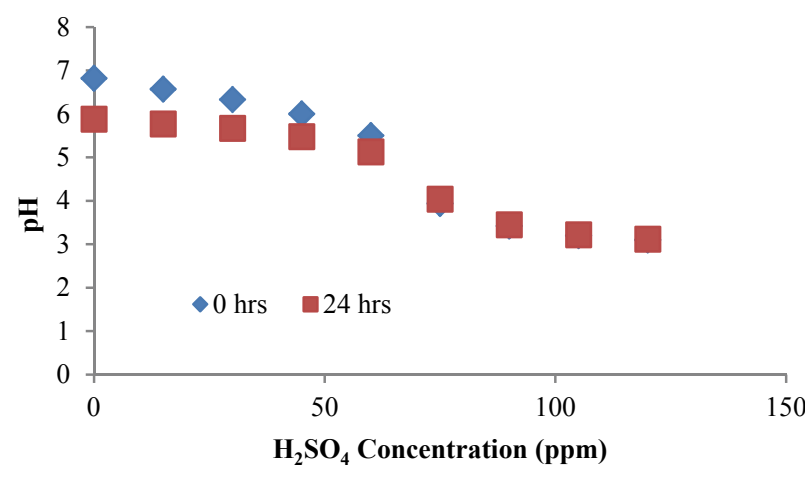

Figure 1. Effect of $\mathrm{H}_{2} \mathrm{SO}_{4}$ concentration on $\mathrm{pH}$ shown for the initial value and after $24 \mathrm{~h}$ of bubbling $3 \% \mathrm{CO}_{2}$. Standard error ranged from 0.00 to $0.06(n=2)$, all of which would be smaller than the data symbols.

in solution. Therefore, an initial experiment without algae was performed to determine the combined effect of the addition $\mathrm{H}_{2} \mathrm{SO}_{4}$ and $\mathrm{CO}_{2}$ on $\mathrm{pH}$ over a $96 \mathrm{~h}$ cultivation period in the absence of biological activity. Figure 1 shows the $\mathrm{pH}$ for varying levels of $\mathrm{H}_{2} \mathrm{SO}_{4}$ addition for 0 and $24 \mathrm{~h}$ (with continuous fixed $\mathrm{CO}_{2}$ addition). After the initial $24 \mathrm{~h}$, the $\mathrm{pH}$ remained approximately constant for all further times. At $\mathrm{H}_{2} \mathrm{SO}_{4}$ concentrations of 0 to $60 \mathrm{ppm}$, the $\mathrm{pH}$ remained above 5 . For concentrations of 105 to $120 \mathrm{ppm}$, the $\mathrm{pH}$ leveled off at just above 3. Interestingly, the addition of $\mathrm{CO}_{2}$ was observed to cause an additional decrease in $\mathrm{pH}$ in conjunction with $\mathrm{H}_{2} \mathrm{SO}_{4}$ levels up to $60 \mathrm{ppm}$. For $\mathrm{H}_{2} \mathrm{SO}_{4}$ additions of $75 \mathrm{ppm}$ and above, the observed decrease in $\mathrm{pH}$ was dominated by addition of further $\mathrm{H}_{2} \mathrm{SO}_{4}$ only, resulting from limited acidification values for carbonic acid in equilibrium with gas phase $\mathrm{CO}_{2}$.

The growth curves for Chlorella vulgaris grown for $8 \mathrm{~h}$ with varying amounts of $\mathrm{H}_{2} \mathrm{SO}_{4}$ (0 to $150 \mathrm{ppm}$ ) are shown in figure 2, and the corresponding $\mathrm{pH}$ levels are shown in table 3 . At concentrations above $150 \mathrm{ppm}$, the algae did not survive the $24 \mathrm{~h}$ cultivation time; therefore, only results from viable cultures within the initial $8 \mathrm{~h}$ are included. The growth curves for up to $90 \mathrm{ppm} \mathrm{H}_{2} \mathrm{SO}_{4}$ are all similar, although the $\mathrm{pH}$ decreased as expected with increasing additions of $\mathrm{H}_{2} \mathrm{SO}_{4}$. This indicates that Chlorella vulgaris is capable of compensating for the addition of up to $90 \mathrm{ppm}$ of $\mathrm{H}_{2} \mathrm{SO}_{4}$, which afforded an average $\mathrm{pH}$ of 3.9. On the other hand, there was a noticeable decrease in the dry weight over time at $\mathrm{H}_{2} \mathrm{SO}_{4}$ concentrations of 120 and $150 \mathrm{ppm}$. The $\mathrm{pH}$ values associated with these two affected growth curves are 3.3 and 3.1 , respectively. 


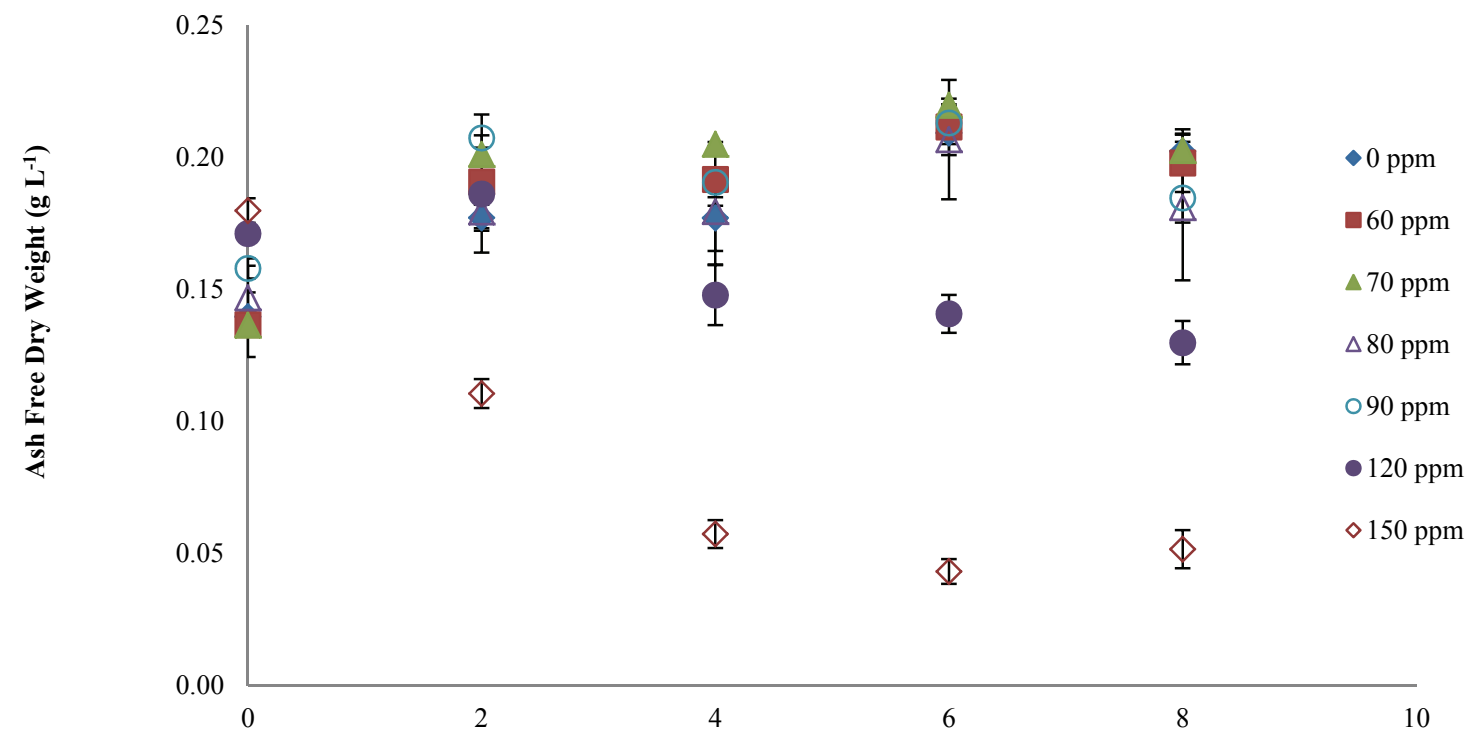

Cultivation Time (h)

Figure 2. Growth curves for Chlorella vulgaris obtained at different $\mathrm{H}_{2} \mathrm{SO}_{4}$ concentrations. Error bars represent standard errors $(n=3)$.

The growth curves for Scenedesmus grown for $8 \mathrm{~h}$ with varying amounts of $\mathrm{H}_{2} \mathrm{SO}_{4}$ (0 to $\left.150 \mathrm{ppm}\right)$ are shown in figure 3 , and the corresponding $\mathrm{pH}$ values are shown in table 3. Again, the growth curves for up to $90 \mathrm{ppm} \mathrm{H}_{2} \mathrm{SO}_{4}$ are all similar. The doubling time for Scenedesmus cultivated in 0 to $90 \mathrm{ppm} \mathrm{H}_{2} \mathrm{SO}_{4}$ is approximately $8 \mathrm{~h}$, with the initial concentration of $0.04 \mathrm{~g} \mathrm{~L}^{-1}$. In contrast, within $8 \mathrm{~h}$, the mass gain for Chlorella is about $30 \%$, with the initial concentration of $0.15 \mathrm{~g} \mathrm{~L}^{-1}$. Moreover, the $\mathrm{pH}$ level again decreased as the amount of $\mathrm{H}_{2} \mathrm{SO}_{4}$ increased; however, it was not as drastic as the decrease seen with Chlorella vulgaris. This indicates that Scenedesmus is more capable of

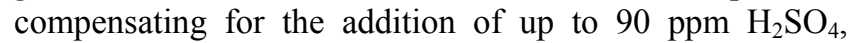
which produced an average $\mathrm{pH}$ of 5.5. There was a noticeable decrease in the Scenedesmus dry weight over time for 120 and $150 \mathrm{ppm}$ of $\mathrm{H}_{2} \mathrm{SO}_{4}$, although not as drastic as that seen with Chlorella vulgaris. The $\mathrm{pH}$ values associated with the 120 and $150 \mathrm{ppm}$ Scenedesmus growth curves were 3.7 and 3.3, respectively. The experiment with Chlorella had a four-fold higher concentration $\left(0.15 \mathrm{~g} \mathrm{~L}^{-1}\right.$ for Chlorella and $0.04 \mathrm{~g} \mathrm{~L}^{-1}$ for Scenedesmus), where typically a higher biomass concentration translates into a higher $\mathrm{pH}$. However, the $\mathrm{pH}$ values for the Chlorella experiment, 3.3 and 3.1 for 120 and $150 \mathrm{ppm}$, respectively, were not higher. Scenedesmus appears to deal with the increase in $\mathrm{H}_{2} \mathrm{SO}_{4}$

Table 3. Average $\mathrm{pH}$ and the beginning $(t=0)$ and end of the $8 \mathrm{~h}$ experiment with varying amounts of $\mathrm{H}_{2} \mathrm{SO}_{4}$.

\begin{tabular}{|c|c|c|c|c|}
\hline \multirow{3}{*}{$\begin{array}{c}\mathrm{H}_{2} \mathrm{SO}_{4} \\
(\mathrm{ppm})\end{array}$} & \multicolumn{4}{|c|}{ Culture $\mathrm{pH} \pm$ standard error $(n=3)$} \\
\hline & \multicolumn{2}{|c|}{ Scenedesmus } & \multicolumn{2}{|c|}{ Chlorella } \\
\hline & $t=0$ & $t=8$ & $t=0$ & $t=8$ \\
\hline 0 & $7.13 \pm 0.02$ & 6.2 & $6.68 \pm 0.02$ & $6.05 \pm 0.01$ \\
\hline 70 & $6.2 \pm 0.01$ & 5.7 & $5.58 \pm 0.04$ & $5.06 \pm 0.06$ \\
\hline 80 & $5.95 \pm 0.01$ & 5.6 & $4.61 \pm 0.05$ & $4.12 \pm 0.27$ \\
\hline 90 & $5.73 \pm 0.05$ & 5.4 & $3.93 \pm 0.05$ & $3.73 \pm 0.03$ \\
\hline 120 & $3.66 \pm 0.03$ & 3.8 & $3.23 \pm 0.04$ & $3.34 \pm 0.03$ \\
\hline 150 & $3.27 \pm 0.01$ & 3.3 & $3.01 \pm 0.01$ & $3.11 \pm 0.01$ \\
\hline
\end{tabular}

better, as seen by the increase in the $\mathrm{pH}$ with less biomass. In either case, the $90 \mathrm{ppm}$ level appears to be a threshold level at which a net decrease in algal mass is to be expected.

The initial growth rates $\left(\mathrm{g} \mathrm{mL}^{-1} \mathrm{~h}^{-1}\right)$ for the first $6 \mathrm{~h}$ of cultivation for Scenedesmus and Chlorella are shown in table 4. These results show that overall Scenedesmus retained a higher growth rate with increasing acidity. There was a statistical difference between the growth rate at $150 \mathrm{ppm}$ and at all the lower concentrations. For $120 \mathrm{ppm}$, all of the treatments were statistically different except $90 \mathrm{ppm}$ for Scenedesmus. The negative growth rate for Chlorella at 120 and $150 \mathrm{ppm}$ is most likely do to cell lysing.

For $\mathrm{H}_{2} \mathrm{SO}_{4}$ levels at $90 \mathrm{ppm}$ and above, the effect of using a buffer $\left(1 \mathrm{~g} \mathrm{~L}^{-1} \mathrm{NaHCO}_{3}\right)$ was tested with Scenedesmus. The results are compared to the growth rates without $\mathrm{H}_{2} \mathrm{SO}_{4}$ in figure 4. The growth rates for Scenedesmus without buffer are similar up to $80 \mathrm{ppm}$, while there is a decrease for 90 and $120 \mathrm{ppm}$ (fig. 3) during the $8 \mathrm{~h}$ cultivation period. However, for the buffered system, the growth rate is similar for $\mathrm{H}_{2} \mathrm{SO}_{4}$ concentrations up to and including $120 \mathrm{ppm}$ for a cultivation period of $96 \mathrm{~h}$.

\section{EFFECT OF ASH}

For ash toxicity tests using Scenedesmus, $5 \mathrm{~g} \mathrm{~L}^{-1}$ of each ash sample (Ash F-19\%, Ash C-1\%, and Ash F-11\%) was added to the algae culture. The resulting growth curves are shown in figure 5 . In each case, the starting $\mathrm{pH}$ of the culture was adjusted to 6.7 before the addition of the ash samples, while the initial biomass content ranged between 0.07 and $0.31 \mathrm{~g} \mathrm{~L}^{-1}$. For Ash $\mathrm{C}-1 \%$, the $\mathrm{pH}$ increased to 11.25 upon addition of the ash sample but decreased to 6.84 after $28 \mathrm{~h}$. Visually, the increase in $\mathrm{pH}$ appeared to kill the algae culture. Algae appeared pale yellow-green to opaque white 


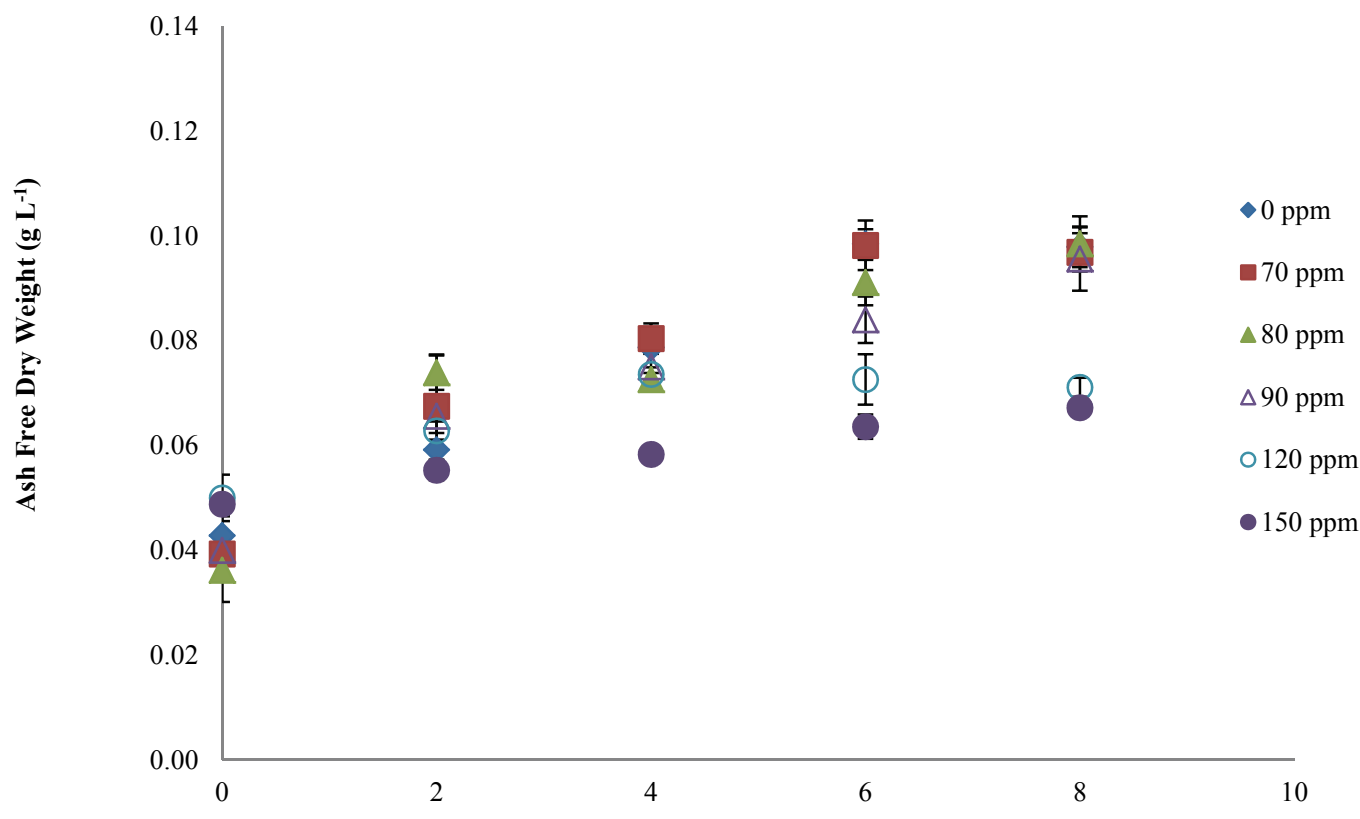

Cultivation Time (h)

Figure 3. Growth curves for Scenedesmus obtained at different $\mathrm{H}_{2} \mathrm{SO}_{4}$ concentrations. Error bars represent standard errors $(n=3)$.

Table 4. Average initial growth rate based on the first $6 \mathrm{~h}$ of growth for Scenedesmus and Chlorella with varying amounts of $\mathrm{H}_{2} \mathrm{SO}_{4}{ }^{\text {|al }}$

\begin{tabular}{ccc}
\hline $\mathrm{H}_{2} \mathrm{SO}_{4}$ & \multicolumn{2}{c}{ Initial Growth Rate $\left(\mathrm{mg} \mathrm{L}^{-1} \mathrm{~h}^{-1}\right)$} \\
\cline { 2 - 3 }$(\mathrm{ppm})$ & Scenedesmus & Chlorella \\
\hline 0 & $9.56 \pm 0.99 \mathrm{a}$ & $11.61 \pm 0.42 \mathrm{wx}$ \\
70 & $9.81 \pm 1.10 \mathrm{a}$ & $13.87 \pm 0.59 \mathrm{x}$ \\
80 & $9.14 \pm 0.78 \mathrm{a}$ & $9.98 \pm 1.03 \mathrm{wx}$ \\
90 & $7.34 \pm 0.62 \mathrm{ab}$ & $9.19 \pm 1.08 \mathrm{wx}$ \\
120 & $3.77 \pm 1.05 \mathrm{~b}$ & $-5.07 \pm 1.24 \mathrm{y}$ \\
150 & $2.48 \pm 0.24 \mathrm{c}$ & $-22.78 \pm 0.35 \mathrm{z}$ \\
\hline
\end{tabular}

a] Values are means \pm standard error $(n=3)$. Means followed by the same letter are not statistically different $(\alpha=0.05)$.

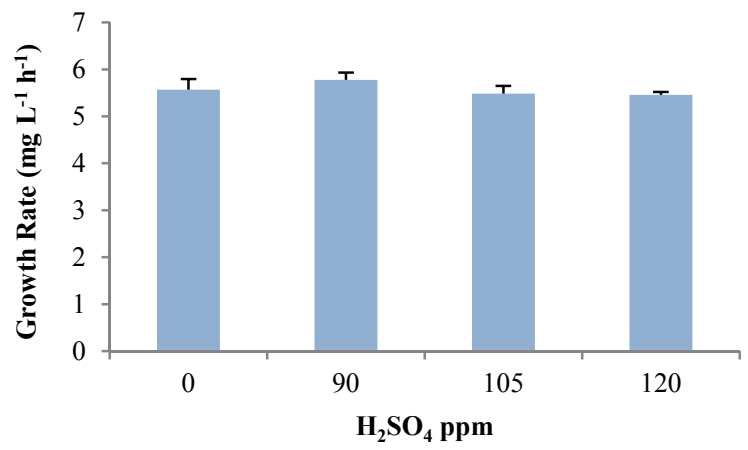

Figure 4. Growth rate of Scenedesmus as a function of $\mathrm{H}_{2} \mathrm{SO}_{4}$ concentration during $96 \mathrm{~h}$ culturing in the presence of $1 \mathrm{~g} \mathrm{~L}^{-1} \mathrm{NaHCO}_{3}$ as a buffer. Error bars represent standard errors $(n=3)$.

in color and settled to the bottom. There was a slight decrease in biomass from 0 to $27 \mathrm{~h}$, after which the biomass content increased. For Ash F-11\%, the pH increased to 6.97 after the addition of ash but returned to approximately the same $\mathrm{pH}$ as the control after $50 \mathrm{~h}$. There was a noticeable decline in the biomass health at the beginning of the culture period, although the culture recovered, such that an increase in biomass mass was seen over the last $36 \mathrm{~h}$ of the culture period. For Ash F-19\%, the pH increased to 7.1 after the addition of ash and returned to approximately the same $\mathrm{pH}$ as the control after $75 \mathrm{~h}$. The growth rates for the control, Ash C-1\%, Ash F-11\%, and Ash F-19\% treatments were $7.0,1.9,2.0$, and $6.0 \mathrm{mg} \mathrm{L}^{-1} \mathrm{~h}^{-1}$, respectively (calculated from the data shown in fig. 5). While all three ash samples appeared to inhibit the growth of Scenedesmus, the growth observed for Ash F-19\% was not significantly different from that of the control $(\mathrm{p}=0.155)$. The growth rates for Ash C-1\% and Ash F-11\% were statistically the same $(p=0.137)$, and they were both statistically different from the control (p-values of 0.0007 and 0.001 , respectively). Ash F-19\% has the highest amount of residual carbon (19\%). The presence of other components in the ash most likely inhibited growth the same as the other ashes did, but the excess carbon offset that effect by enhancing growth. However, this would not be the ideal case because this would mean the algae was not consuming as much of the $\mathrm{CO}_{2}$.

Calculation of the atomic $\mathrm{Ca}: \mathrm{S}$ ratio for Ash $\mathrm{C}-1 \%$ gives a value of 3.3:1 (assuming that all of the sulfur is present as $\left.\mathrm{CaSO}_{4}\right)$. The $\mathrm{Ca}: \mathrm{S}$ ratio indicates that a significant fraction of the calcium $(70 \%)$ is not bound up as sulfate, i.e., is present as $\mathrm{CaO}$ (given that there are no other anions present in significant concentration that could balance the $\mathrm{Ca}^{2+}$ ions). This explains why the $\mathrm{pH}$ of the Scenedesmus culture increased to 11.25 upon addition of Ash C-1\%. Consequently, highly efficient ash removal from the flue gas would be required before algae could be used as a $\mathrm{CO}_{2}$ scrubbing strategy for the Ash C-1\% plant. 


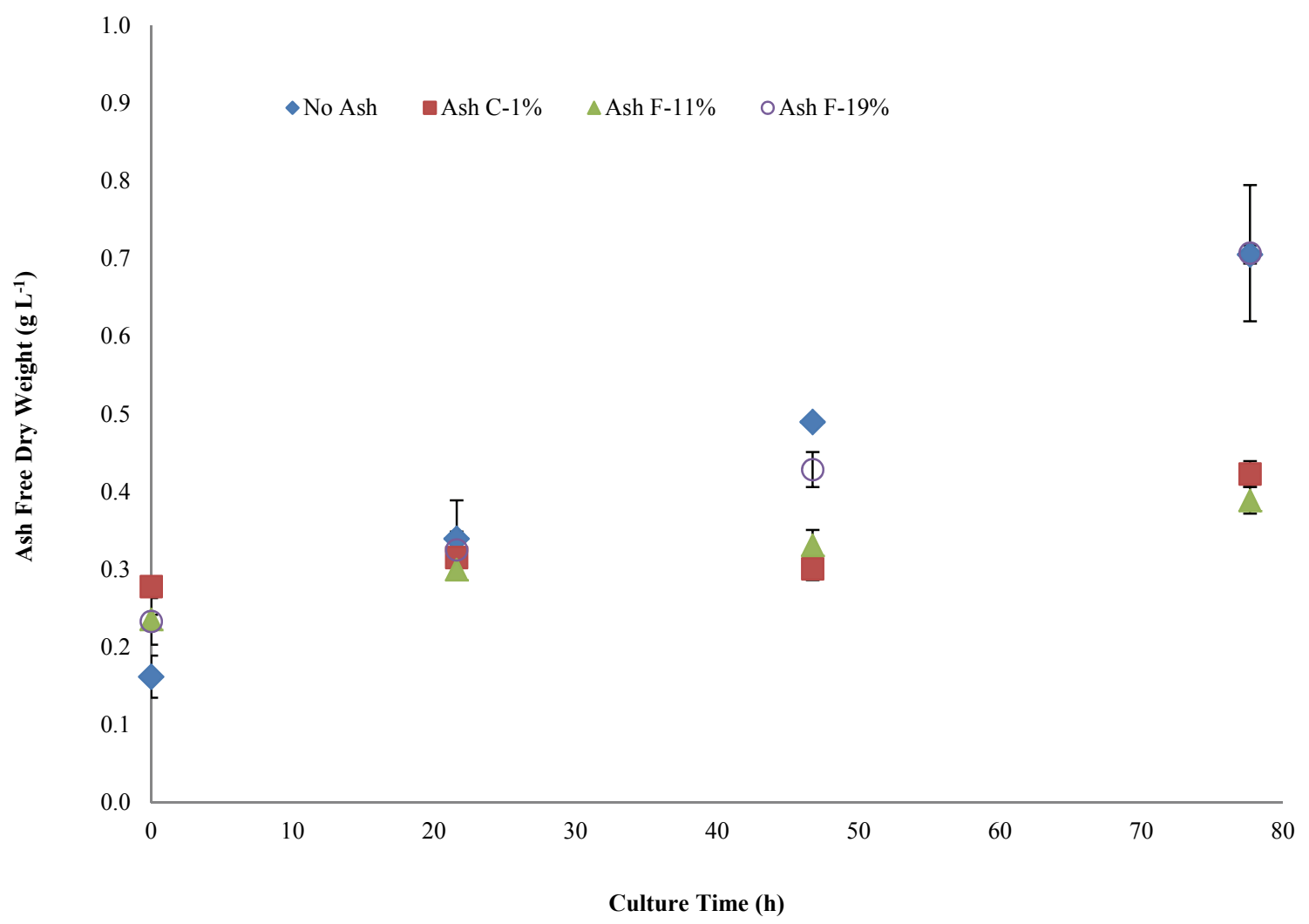

Figure 5. Growth curves for Scenedesmus obtained with the addition of $5 \mathrm{~g} \mathrm{~L}^{-1}$ of ash from various coal-fired power plants in Kentucky. Error bars represent standard errors $(n=3)$.

The Ash F-19\% and Ash F-11\% plants use midAppalachian coal as a feedstock in typical combustors, producing Class $\mathrm{F}$ ash, which usually contains residual carbon. The Ash F-19\% plant is small and usually produces an ash containing a substantial amount of unburned carbon content. As shown in table 2, this value can approach $20 \%$ by weight, whereas the value for the larger Ash F-11\% plant is typically close to $10 \%$. Due to the high carbon content of these ashes, they are black in color; hence, the presence of high ash concentrations during culturing leads to darkening of the culture medium and decreased light penetration into the culture. For Ash F-19\% and Ash F-11\% this effect is noticeable, whereas the change in culture $\mathrm{pH}$ upon addition of the ashes was minor (as described above). The latter effect reflects the relatively low concentrations of free alkali metal oxides and alkaline earth oxides present in the ashes. Other than the carbon content, the compositions of these two ashes are similar, and both contain useful amounts of trace elements (V, Mo, Co, Zn, etc.), which are frequently required for algae growth (Kaplan et al., 1986). Although the dissolution of these metal oxides is expected to be appreciable only at low $\mathrm{pH}$ values $(<5)$, the fact that they are present in ppm levels suggests that sufficient amounts may dissolve during culturing to supply the $\mathrm{ppb}$ levels typically required for these micronutrients.

Additional studies were performed to examine the effect of lowering the concentration of the different ashes during algae culturing (fig. 6). At the lowest ash concen- tration examined $\left(0.025 \mathrm{~g} \mathrm{~L}^{-1}\right)$, Ash F-11\% had a growth rate that was not statistically different from the control (without ash). Moreover, for all three ash types tested at the $0.025 \mathrm{~g} \mathrm{~L}^{-1}$ level, the growth rates were not statistically different from each other or the control. For the two higher concentrations $\left(0.25\right.$ and $\left.0.5 \mathrm{~g} \mathrm{~L}^{-1}\right)$, there was a significant difference in each case between the ash samples and the control, but there was no significant differences between the measured growth rates for the different ash types at the same loading. Vocke (1979) found a significant change in the growth of a Scenedesmus algae using as little as $0.0001 \mathrm{~g} \mathrm{~L}^{-1}$ of an extract from a western coal-fired generation plant. In contrast, for all three of our ash samples, there were no statistically significant differences in growth rate at the $0.025 \mathrm{~g} \mathrm{~L}^{-1}$ level. However, one of the conclusions from the work of Vocke (1979) was that toxicity is very algae- and ash-dependent, which may explain the discrepancy.

For the toxicity tests with Chlorella vulgaris, $5 \mathrm{~g} \mathrm{~L}^{-1}$ of each ash sample (Ash F-19\%, Ash C-1\%, and Ash F-3\%) was added to the algae culture and grown for five days (fig. 7). The starting $\mathrm{pH}$ of the culture was adjusted to 6.7 before the addition of the ash samples. For Ash C-1\%, the $\mathrm{pH}$ increased to 9.57 upon addition of the ash sample and increased to as high as 11.08 after $24 \mathrm{~h}$. Visually, the increase in $\mathrm{pH}$ appeared to kill the algae culture. Although there was a slight decrease in biomass from 0 to $20 \mathrm{~h}$, after $20 \mathrm{~h}$ the biomass content remained constant. For Ash F-3\%, 


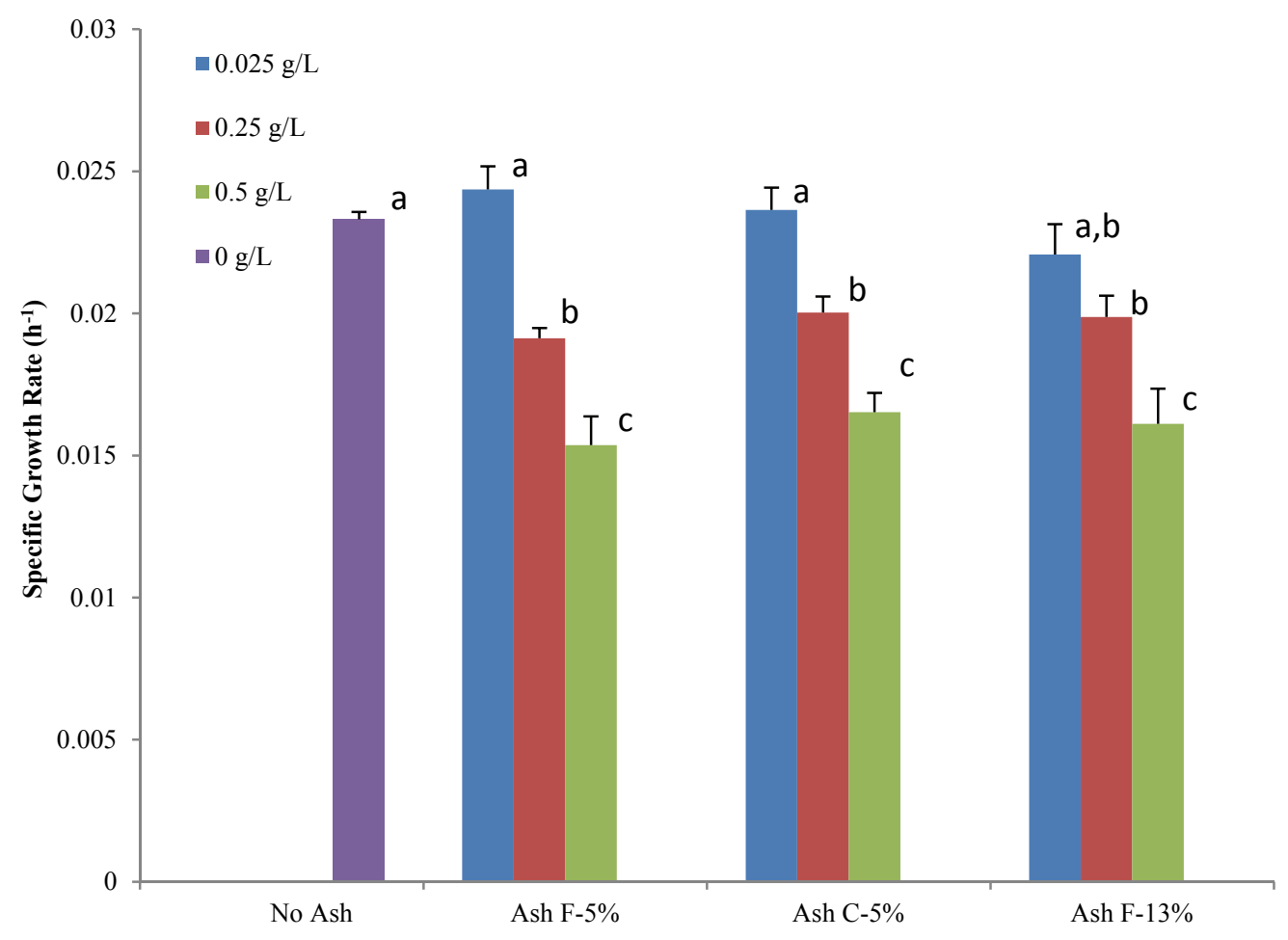

Figure 6. Growth rate of Scenedesmus grown with three different ash types at three different loadings compared to a control. Error bars represent standard errors $(n=3)$, and treatments with the same letter are not statistically different with $\alpha=0.05$.

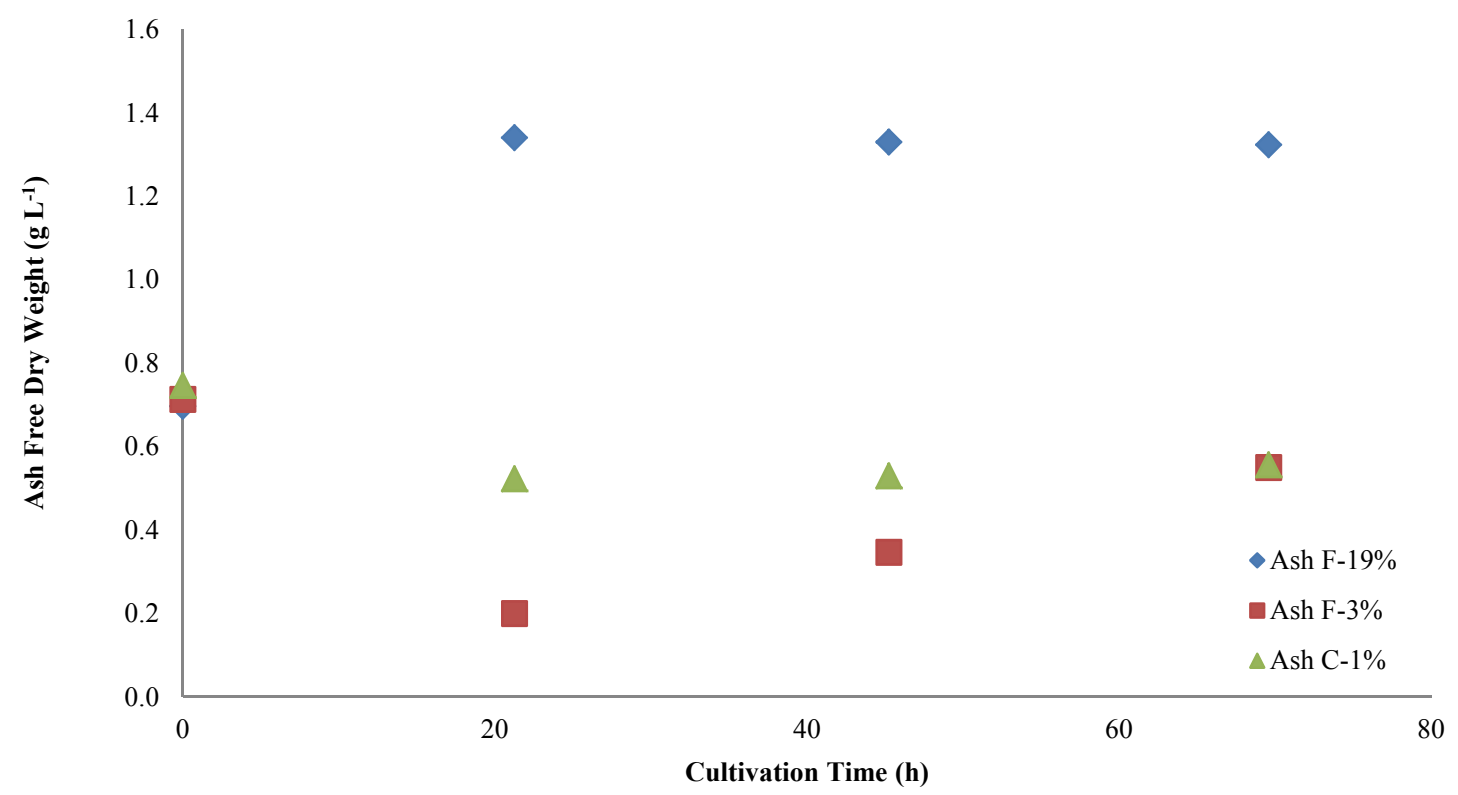

Figure 7. Growth curves for Chlorella vulgaris obtained with the addition of $5 \mathrm{~g} \mathrm{~L}^{-1}$ of ash from various coal-fired power plants in Kentucky.

the $\mathrm{pH}$ increased to 6.95 after the addition of ash and peaked at 9.41 at $48 \mathrm{~h}$. There was a noticeable decline in the biomass health in the beginning of the experiment, but interestingly the culture appeared to recover, and an increase in biomass was seen over the last three days of cul- ture. For Ash F-19\%, the pH increased to 7.05 after the addition of ash and peaked at 8.35 after $24 \mathrm{~h}$ of culturing, decreasing to 8.19 at $72 \mathrm{~h}$. The increase in $\mathrm{pH}$ did not appear to impair the growth of the culture. In fact, the culture grew well, reaching a maximum concentration of $1.2 \mathrm{~g} \mathrm{~L}^{-1}$ 
after the first $24 \mathrm{~h}$. These results support the conclusions from the ash toxicity test with Scenedesmus, i.e., that Ash F-19\% does not greatly affect the growth rate, whereas Ash C-1\% exerts a significant inhibitory effect.

These data can be used to evaluate the potential impact of ash from different power plant designs. If a biomitigation strategy is to be employed at a facility that produces a Class F ash, such as Ash F-19\% and Ash F-3\%, few problems associated with ash contamination would be expected. Indeed, the foregoing results suggest that it is possible that the presence of minute amounts of ash has the potential to improve the growth rate, as seen with Ash F$5 \%$, but at the same time it might also adversely affect the growth rate, as seen with Ash C-1\%. Further ash tolerance studies will need to be done with the ash specifically used in each installation, unless the exposure level can be limited to below $0.025 \mathrm{~g} \mathrm{~L}^{-1}$.

$\mathrm{SO}_{\mathrm{x}}$ and ash components were chosen for this study because they are likely to be the most influential components of flue gas on algae growth in an algal $\mathrm{CO}_{2}$ mitigation system. Obviously, other components will likely need to be addressed before commercialization, but most are in such trace amounts (or likely beneficial, e.g., $\mathrm{NO}_{\mathrm{x}}$ ) as to be of little primary concern. Studying both $\mathrm{SO}_{\mathrm{x}}$ and ash together is a logical approach, as any system without $\mathrm{SO}_{\mathrm{x}}$ scrubbers will release both ash and $\mathrm{SO}_{\mathrm{x}}$ together, whereas a scrubbed system will still introduce ash. By looking closer at the most influential component in the gas phase $\left(\mathrm{SO}_{\mathrm{x}}\right)$ and the effect of the solid particles in the flue gas, we have actually found counter influences. This suggests that the analysis of the entire flue gas system will involve several connected influences.

\section{CONCLUSIONS}

The influence of possible flue gas contaminants on the growth rate of two microalgae strains, Chlorella vulgaris and Scenedesmus acutus, was investigated. These two strains of algae are interesting candidates for large-scale cultivation to mitigate $\mathrm{CO}_{2}$ emissions from coal-fired power plants. To study the influence of $\mathrm{SO}_{\mathrm{x}}$ and ash on the viability of an algal scrubber system, elevated $\mathrm{H}_{2} \mathrm{SO}_{4}$ (as surrogate for $\mathrm{SO}_{x}$ ) levels and the effect of ash were investigated. While the $\mathrm{H}_{2} \mathrm{SO}_{4}$ concentration influenced the $\mathrm{pH}$ and subsequent growth, the addition of a buffer $\left(\mathrm{NaHCO}_{3}\right)$ was found to minimize the effect. These results indicate that between standard power plant $\mathrm{SO}_{\mathrm{x}}$ management practices and carbonate buffering of the growth media, the introduction of $\mathrm{SO}_{\mathrm{x}}$ and its subsequent hydration products are manageable without deleterious effect on the algal system.

The introduction of ash had varying effects depending on the source of the ash. In all cases, it appears that ash addition had some negative effect on algae growth. However, in one case, due to a high carbon content, the ash addition was seen to overcome this inhibitory effect and enhance growth. Based on the broad set of ash samples (both Class $\mathrm{C}$ and Class F) from various power plant types used in this study, the results indicate that no catastrophic outcomes result from the carryover of ash into the algae sys- tem at concentrations of $0.025 \mathrm{~g} \mathrm{~L}^{-1}$ or less.

Overall, this study indicates that the primary components of the flue gas from a coal-fired power plant will not prevent use of an algal scrubbing system. While the results indicate that different plant configurations will require adaptation of the growth media to some extent, they do not show any major obstacles to the next development stages of this technology. Rather, these results indicate the ability of an algal system to serve as a multi-component scrubbing system, handling both residual ash carryover and $\mathrm{SO}_{\mathrm{x}}$. Under scaled-up conditions, this could allow for reduced burdens on upstream emissions control units and thereby reduce the overall energy parasitism and capital costs for the plant.

With the growing desire to address carbon dioxide emissions, which are associated with increasing rates of climate change, innovative processes are needed to capture carbon dioxide from major point sources such as fossil fuel power plants. In this work, major technical hurdles in the use of algal scrubbing systems are being addressed with respect to major contaminants in coal-derived flue gases. With such knowledge, mitigation systems can be developed to reduce overall capital and operating costs of the emissions controls for a plant, and make algal scrubbing economically viable.

\section{ACKNOWLEDGEMENTS}

The authors would like to thank the Kentucky Department of Energy Development and Independence for funding.

\section{REFERENCES}

Becker, E. W. 1994. Growth kinetics. In Microalgae: Biotechnology and Microbiology, 51-62. Cambridge, U.K.: Cambridge University Press.

Crofcheck, C. X. E, A. Shea, M. Montross, M. Crocker, and R. Andrews. 2012. Influence of media composition on the growth rate of Chlorella vulgaris and Scenedesmus acutus utilized for $\mathrm{CO}_{2}$ mitigation. J. Biochem. Tech. 4(2): 589-594.

de-Bashan, L. E., A. Trejo, V. A. R. Huss, J. P. Hernandez, and Y. Bashanl. 2008. Chlorella sorokiniana UTEX 2805, a heat and intense, sunlight-tolerant microalga with potential for removing ammonium from wastewater. Bioresource Tech. 99(11): 49804989.

Desideri, U., and A. Paolucci. 1999. Performance modeling of a carbon dioxide removal system for power plants. Energy Conversion and Mgmt. 40(18): 1899-1915.

EIA. 2009. Emissions of greenhouse gases in the United States 2008. Washington, D.C.: U.S. Department of Energy, Energy Information Administration. Available at: www.eia.gov/oiaf/ 1605/ggrpt/pdf/0573(2008).pdf. Accessed 14 May 2013.

Graham, L. E., and L. W. Wilcox. 2000. Introduction to the algae: Occurrence, relationships, nutrition, definition, general features. In Algae, 1-21. Upper Saddle River, N.J.: Prentice-Hall.

Hauck, J. T., G. J. Olson, S. J. Scierka, M. B. Perry, and M. M. Ataai. 1996. Effects of simulated flue gas on growth of microalgae. In Preprints of Papers of National Meeting of the American Chemical Society 212: 1391-1396. Washington, D.C.: American Chemical Society.

Ho, S. H., C. Y. Chen, D. J. Lee, and J. S. Chang. 2011. Perspectives on microalgal $\mathrm{CO}_{2}$ emission mitigation systems: A review. Biotech. Advances 29(2): 189-198. 
Hower, J. C., T. L. Robl, G. A. Thomas, S. D. Hopps, and M. Grider. 2009. Chemistry of coal and coal combustion products from Kentucky power plants: Results from the 2007 sampling, with emphasis on selenium. Coal Combustion and Gasification Products 1(1): 50-62.

Kaplan, D., A. E. Richmond, Z. Dubinsky, and S. Aaronson. 1986. Algal nutrition. In Handbook of Microalgal Mass Culture, $147-$ 198. A. Richmond, ed., Boca Raton, Fla.: CRC Press.

Lee, J. S., D. K. Kim, J. P. Lee, S. C. Park, J. H. Koh, H. S. Cho, and S. W. Kim. 2002. Effects of $\mathrm{SO}_{2}$ and $\mathrm{NO}$ on growth of Chlorella sp. KR-1. Bioresource Tech. 82(1): 1-4.

Loerting, T., R. T. Kroemerb, and K. R. Liedl. 2000. On the competing hydrations of sulfur dioxide and sulfur trioxide in our atmosphere. Chem. Commun. 12: 999-1000.

Maeda, K., M. Owada, N. Kimura, K. Omata, and I. Karube. 1995. $\mathrm{CO}_{2}$ fixation from the flue gas on coal-fired thermal power plant by microalgae. Energy Conversion and Mgmt. 36(6-9): 717-720.

Matsumoto, H., A. Hamasaki, and N. Sioji. 1997. Influence of $\mathrm{CO}_{2}$, $\mathrm{SO}_{2}$, and $\mathrm{NO}$ in flue gas on microalgae productivity. J. Chem. Eng. Japan 30(4): 620-624.

Morais, M. G., and H. A. V. Costa. 2007. Isolation and selection of microalgae from coal-fired thermoelectric power plant for biofixation of carbon dioxide. Energy Conversion and Mgmt. 48(7): 2169-2173.

Olaizola, M. 2003. Microalgal removal of $\mathrm{CO}_{2}$ from flue gases:
Changes in medium $\mathrm{pH}$ and flue gas composition do not appear to affect the photochemical yield of microalgal cultures. Biotech. and Bioproc. Eng. 8(6): 360-367.

Sakai, N., Y. Sakamoto, N. Kishimoto, M. Chihara, and I. Karube. 1995. Chlorella strains from hot springs tolerant to high temperature and high $\mathrm{CO}_{2}$. Energy Conversion and Mgmt. 36(69): 693-696.

Sayre, R. 2010. Microalgae: The potential for carbon capture. BioScience 60(9): 722-727.

Vocke, R. W. 1979. Growth responses of selected freshwater algae to trace elements and scrubber ash slurry generated by coal-fired power plants. Oak Ridge, Tenn.: U.S. Department of Energy, Office of Scientific and Technical Information. Available at www.osti.gov/energycitations/product.biblio.jsp?osti_id=644664 5. Accessed 14 May 2013.

Wang, B., Y. Li, N. Wu, and C. Q. Lan. 2008. $\mathrm{CO}_{2}$ bio-mitigation using microalgae. Appl. Microbiol. and Biotech. 79(5): 707-718.

Westerhoff, P., Q. Hu, M. Esparza-Soto, and W. Vermaas. 2010. Growth parameters of microalgae tolerant to high levels of carbon dioxide in batch and continuous-flow photobioreactors. Environ. Tech. 31(5): 523-532.

Zeiler, K. G., D. A. Heacox, S. T. Toon, K. L. Kadam, and L. M. Brown. 1995. The use of microalgae for assimilation and utilization of carbon dioxide from fossil fuel-fired power plant flue gas. Energy Conversion and Mgmt. 36(6-9): 707-712. 